\title{
PEMBELAJARAN BOUNDED INQUIRY LABS UNTUK MENINGKATKAN PENGUASAAN KONSEP DAN KEMAMPUAN BERPIKIR ANALISIS SISWA PADA TOPIK HIDROLISIS GARAM
}

\author{
Henrikus Suparjono ${ }^{1,2}$, Indarini Dwi Pursitasari ${ }^{2}$, Leny Heliawati ${ }^{2}$ \\ ${ }^{1}$ SMA Kanisius Jakarta \\ ${ }^{2}$ Program Studi IPA Sekolah Pascasarjana Universitas Pakuan Bogor \\ *E-mail: henrikussuparjono@gmail.com
}

\begin{abstract}
Abstrak: Hidrolisis garam merupakan salah satu materi pelajaran kimia yang diajarkan di kelas XI SMA. Sebagian besar (60\%) siswa menyatakan materi hidrolisis garam tergolong sukar.Tujuan dari penelitian ini adalah untuk menerapkan pembelajaran bounded inquiry labs untuk meningkatkan penguasaan konsep dan kemampuan berpikir analisis siswa pada topik hidrolisis garam. Metode dalam penelitian ini adalah kuasi eksperimen dengan desain Nonequivalen Pretest-Posttest Control Group Design. Ada dua kelompok sampel yaitu kelompok eksperimen dan kelompok kontrol yang dipilih secara purposive sampling. Kelas kontrol dengan pembelajaran langsung dan kelas eksperimen dengan pembelajaran bounded inquiry labs. Instrumen sudah divalidasi dan reliabel. Data yang terkumpul dianalisis secara deskriptif dan inferensial. Hasil penelitian yang terdiri dari penguasaan konsep dan kemampuan berpikir analisis menunjukkan terdapat kenaikan $\mathrm{N}$-gain antara kelas kontrol dan kelas eksperimen. Hasil uji statistik dengan uji t-Test diperoleh signifikansi (sig.(2-tailed)) sebesar 0,019 untuk penguasaan konsep dan 0,002 untuk kemampuan berpikir analisis, yang berarti < dari 0,005 menunjukkan terdapat perbedaan yang signifikan antara penguasaan konsep kelas kontrol maupun kelas eksperimen. Hasil ini diperkuat dengan tanggapan siswa yang menyatakan siswa lebih termotivasi dalam mengikuti pembelajaran BIL dan mereka terbantu dalam pencapaian nilai ulangan yang labih baik.
\end{abstract}

Kata Kunci: Penguasaan Konsep, Kemampuan Berpikir Analisis, Bounded Inquiry Labs, Hidrolisis Garam

\section{PENDAHULUAN}

Kimia merupakan mata pelajaran di SMA yang sebagaian besar siswa menyatakan mata pelajaran ini adalah tergolong sukar. Untuk menguasai konsep kimia tidak hanya memerlukan kemampuan menghafal rumus-rumus yang ada, tetapi juga diperlukan kemampuan menganalisis fakta atau peristiwa dan sifatsifat dari suatu materi sehingga siswa dapat menemukan sendiri rumus-rumus atau dapat menyelesaikan permasalahan yang dihadapi. Menurut Dahar (2011) yang disebut konsep adalah serangkaian objek, fakat atau kegiatan yang mempunyai ciri-ciri yang sama yang digunakan untuk mendapatkan dan mengomunikasikan 
pengetahuan. Penguasaan konsep merupakan kemampuan untuk mengerti atau mengetahui konsep setelah mendapatkan pengajaran atau pembelajaran. Dalam hal ini peran guru sangat penting untuk mengajak siswa untuk berpikir ke tingkat kemampuan berpikir tingkat tinggi. Guru mengajak siswa untuk mencari permasalahan yang timbul dan mencari pemecahannya. Tak sedikit guru sudah mengupayakan dengan berbagai cara untuk meningkatkan kemampuan siswa dalam mempelajari kimia, salah satunya adalah dengan dengan melakukan kegiatan laboratorium atau praktikum. Namun percobaan atau praktikum tersebut hanya sekedar membuktikan teori yang sudah ada tanpa diarahkan untuk mencari permasalahan yang ada dan menemukan teori yang sejalan atau hampir sama dengan teori yang sudah ada.

Keberhasilan penguasaan materi kimia tidak hanya ditentukan oleh kemapuan seorang guru, namun juga didukung oleh kemampuan siswa, saranaprasarana yang baik serta bahan ajar yang baik. Kemampuan siswa yang sangat mendukung dalam penguasaan materi kimia adalah kemampuan berpikir tingkat tinggi yaitu kemampuan berpikir analisis. Kemampuan berpikir analsis berpusat pada siswa dan tidak mungkin dikusasi oleh siswa apabila tidak menguasai aspekaspek kognitif sebelumnya. Menurut Sudjana (2005), analisis merupakan merupakan tipe yang kompleks karena memanfaatkan unsur pengetahuan, pemahaman dan aplikasi. Herdian (2010) mengemukakan bahwa menganalisis merupakan kemampuan memisahkan materi (informasi) ke dalam bagianbagiannya, mencari hubungan antar bagian-bagian tersebut, mampu melihat (mengenal) komponen-komponennya, bagaimana komponen-komponen itu berhubungan dan terorganisasikan serta membedakan fakta dari hayalan.

Berpikir analitis adalah kemampuan untuk membedakan, mengkategorikan bagian-bagian dari suatu peristiwa untuk mengetahui hal pentig apa, bagaimana bagian-bagian itu terkait, apa penyebab/efek, dan apa alasan yang mendasarinya. Berpikir analisis adalah semacam rangkaian perilaku yang membutuhkan inkuiri lebih lanjut dari parameter yang kurang terdefinisi dengan baik. Berpikir analisis dibutuhkan saat seseorang mengalami kesulitan dalam memecahkan masalah (Robbins, 2011).

Kemampuan seorang guru sangat diperlukan untuk mengajak atau mendampingi siswa untuk berlatih berpikir analisis. Bererapa tahap dalam mengajak siswa berpikir analisis harus dilalui, melatih siswa menguaraikan materi ke dalam bagian-bagiannya, kemudian menuntun siswa untuk mencari keterkatian antar bagian-bagian tersebut dan mengajak siswa membuat argumen dan berpikir sistematis dan dapat menarik kesimpulan dari persoalan-persoalan dalam mempelajari ilmu kimia (Herdian, 2010).

Salah satu cara untuk mengajak siswa berlatih menungkatkan berpikir tingkat tinggi yaitu berpikir analisis adalah dengan pembelajaran inkuiri, 
pembelajaran yang melibatkan siswa secara aktif untuk menemukan permasalahan dan sekaligus menemukan sendiri pemecahannya. Pembelajaran inkuiri terpusat pada siswa, yaitu pembelajaran kolaboratif dengan siklus eksplorasi, penemuan konsep dan aplikasi (De Gale dan Boisselle, 2015).

Wenning (2011) membagi pembelajaran inkuri dalam beberapa tingkatan inkuiri, yaitu dari tingkatan kemampuan rendah dimana posisi guru masih sangat dominan sampai pada tingkat kemampuan yang tinggi dimana siswa berada pada posisi yang dominan. Adapun level atau tungkatan inkuiri sebagai berikut : 1) Discovery Learning, siswa mengembangkan konsep yang berbasis pad pengalaman pertama (berfokus pada keterlibatan aktif dalam membangun suatu pengetahuan); 2) Interactive Demonstration, siswa dilibatkan dalam penjelasan dan pembuatan prediksi yang memungkinkan sehingga guru dapat mengidentifikasi, mengkonfrontasi,dan menyelesaikan konsep alternatif (penanganan pengetahuan sebelumnya); 3) Inquiry Lesson, siswa mengidentifikasi prinsip-prinsip sains adan atau hubungannya (kerja kooperatif untuk membangun pengetahuan yang lebih detil); 4) Inquiry Laboratory, siswa dapat membuat hukum empiris berdasarkan pada pengukuran beberapa variabel (kerja kolaboratif untuk membangun pengetahuan yang lebih detil; 5) Real-world Applications, siswa menyelesaiakn masalah yang berhubungan dangan situasi otentik baik bekerja secara individual atau dalam kelompok kooperatif dan kolaboratif menggunakan pendekatan problem-based dan project-based; 6) Hypothetical Inquiry, siswa dapat menjelaskan dan mengobservasi fenomena (pengalaman yang lebih relistik dari sebuah sain). Inkuiri laboratorium, memfasilitasi siswa untuk menemukan dan menyelesaikan permasalahan, menentukan hipotesis, merancang percobaan, menyajikan data, menganalisa, menarik kseimpulan, dan mengkomunikasikan hasil percobaan.

Siswa dengan kemampuan yang baik perlu ditantang dengan pembejaran inkuiri berbasis praktikum di laboratorium yaitu dengan pembelajaran bounded inquiry labs. Tingkat inkuiri saintifik yang diharapkan paling tepat adalah inquiry labs (inkuiri laboratorium) jenis bounded inquiry labs (laboratorium inkuiri terbatas) dimana guru membimbing dengan bantuan terbatas/dengan pertanyaanpertanyaan pembuka yang sifatnya masih terbatas dalam menemukan masalah , siswa berusaha mencari sendiri pertanyaan lain untuk menuntun pada pemecahan masalah yang dihadapi (Wenning, 2005). Pembelajaran dengan model bounded inquiry labs diharapkan juga dapat meningkatkan kemapuan berpikir analisis siswa, karena dalam pembelajaran yang terpusat pada siswa ini menuntut kemampuan berpikir analisis siswa yang bagus.

Berdasarkan uraian di atas maka pada penelitian ini dapat dirumuskan suatu permasalahan sebagai berikut: Bagaimana pembelajaran bounded inquiry labs terhadap peningkatan dan kemampuan berpikir analisis siswa dalam memecahkan 
masalah kimia khususnya materi hidrolisis garam? Permasalahan pada penelitian ini untuk mengukur perbedaan pencapaian kemampuan berpikir analisis siswa dengan menggunakan pembelajaran bounded inquiry labs dan menggunakan pembelajaran langsung pada pembelajaran topik hidrolisis garam.

Penelitian bertujuan untuk mendeskripsikan perbedaan pencapaian penguasaan konsep dan kemampuan berpikir analisis antara pembelajaran bounded inquiry labs dengan model pembelajaran langsung.

\section{METODE}

Metode dalam penelitian ini adalah penelitian kuasi eksperimen dengan desain Nonequivalen Pretest-Posttest Control Group Design dengan metode kuantitatif. Dengan populasi adalah siswa kelas XI SMA Kanisius Jakarta dan sampel adalah dua kelas dari 6 kelas IPA yang masing-masing terdiri dari 30 siswa yang dipilih secara purposive sampling yaitu kelompok eksperimen dan kelompok kontrol. Kedua kelas diuji dengan uji homogenitas dan normalitas untuk memastikan kedua kelas homogen dan terdistribusi normal.

Kedua Kelompok diberi diberi pretest dan post test (Fraenkel dan Wallen, 2006). Analisa data menghitung gain ternormalisasi tes penguasaan konsep dan kemampuan berpikir analisis siswa dengan rumus $\mathrm{g}$ factor (gain score normalized):

$$
\mathrm{N}-\mathrm{g}=\frac{\text { s post }- \text { s pre }}{\text { S maks }-S \text { pre }}
$$

Keterangan :

$\mathrm{S}_{\text {post }}=$ skor postes

$S_{\text {pre }}=$ skor pretes

$\mathrm{S}_{\text {maks }}=$ Skor maksimal ideal

Sebelum digunakan untuk pretet dan post test, instrumen diuji dengan uji validitas dan uji reliabilitas. Instrumen penguasaan konsep dan kemampuan berpikir analisis dinyatakan valid karena mempunyai $r$ hitung $>0,05 \mathrm{t}$ tabel. Sedangkan hasil uji reliabilitas untuk tes penguasaan konsep dengan harga Cronbach's Alpha $(\mathrm{r})=0,773$, untuk kemampuan berpikir analisis dengan harga Cronbach's Alpha $(r)=0,789$. Dari data tersebut dapat dinyatakan kedua tes reliabel dengan tingkat interpretasi sedang.

Untuk menguji pengaruh pembelajaran bounded inquiry labs terhadap peningkatan penguasaan konsep dan kemampuan berpikir analisis siswa dalam memecahkan masalah kimia khususnya topik hidrolisis garam dengan uji t-Test atau uji kesamaan dua rata-rata (Fraenkel dan Wallen, 2006). 


\section{HASIL DAN PEMBAHASAN}

Kelas kontrol dengan pembelajaran langsung dan kelas eksperimen dengan pembelajaran bounded inquiry labs. Uji homogenitas penguasaan konsep memperoleh signifikansi 0,49 dan terdistribusi normal dengan signifikansi kelas kontrol dan eksperimen masing-masing 0,28 dan 0,07. Uji homogenitas kemampuan berpikir analisis memperoleh signifikansi 0,36 dan terdistribusi normal dengan signifikansi kelas kontrol dan eksperimen masing-masing 0,07 dan 0,40 . Instrumen yang dikembangkan valid dengan koefisien reliabilitas 0,77 pada tes penguasaan konsep dan 0,79 pada tes kemampuan berpikir.

Setelah dilaksanakan pembelajaran langsung pada kelas kontrol dan pembelajaran bounded inquiry labs pada kelas eksperimen maka hasil pencapaian penguasaan konsep dan kemampuan berpikir analisis secara deskripsi terdapat pada Tabel 1, Tabel 2, Gambar 1, Tabel 3, Tabel 4, dan Gambar 5 sebagai berikut:

Tabel 1. Deskripsi Hasil Pretest dan Post Test Penguasaan Konsep Kelas Kontrol dan Kelas Eksperimen

\begin{tabular}{lcccc}
\hline \multirow{2}{*}{ Parameter } & \multicolumn{2}{c}{ Kelompok Kontrol } & Kelompok Eksperimen \\
\cline { 2 - 5 } & Pretest & Postest & Pretest & Postest \\
\hline $\mathrm{N}$ & 30 & 30 & 30 & 30 \\
\cline { 2 - 5 } Minimum & 52.25 & 67.75 & 20.00 & 66.67 \\
Maximum & 92.50 & 100.00 & 92.50 & 100.00 \\
Mean & 75.99 & 86.99 & 62.55 & 87.11 \\
Std.Deviation & 9.072 & 8.856 & 17.975 & 9.252 \\
\hline
\end{tabular}

Tabel 2. Deskripsi Gain Penguasaan Konsep Kelas Kontrol dan Kelas Eksperimen

\begin{tabular}{lcc}
\hline Parameter & Kelas Kontrol & Kelas Eksperimen \\
\hline $\mathrm{N}$ & 30 & 30 \\
\cline { 2 - 3 } Minimum & -1.00 & -0.33 \\
\cline { 2 - 3 } Maximum & 1.00 & 1.00 \\
\cline { 2 - 3 } Mean & 0.398 & 0,656 \\
Std.Deviation & 0.4774 & 0.295 \\
\hline
\end{tabular}






Gambar 1. Hasil Penguasaan Konsep Siswa

Tabel 3. Uji Homogenitas Pretest Kelas Kontrol dan Kelas Eksperimen Kemampuan Berpikir Analisis

\begin{tabular}{lcccc}
\hline \multirow{2}{*}{ Parameter } & \multicolumn{2}{c}{ Kelompok Kontrol } & \multicolumn{2}{c}{ Kelompok Eksperimen } \\
\cline { 2 - 5 } & Pretest & Postest & Pretest & Postest \\
\hline N & 30 & 30 & 30 & 30 \\
Minimum & 40.00 & 56.67 & 23.33 & 73.33 \\
Maximum & 83.33 & 96.67 & 83.33 & 96.67 \\
\cline { 2 - 5 } Mean & 58.67 & 80.56 & 49.22 & 84.78 \\
Std.Deviation & 13.436 & 8.801 & 16.439 & 7.244 \\
\hline
\end{tabular}

Tabel 4. Deskripsi Gain Kelas Kontrol dan Kelas Eksperiman Kemampuan Berikir Analisis

\begin{tabular}{lcc}
\hline Parameter & Kelas Kontrol & Kelas Eksperimen \\
\hline $\mathrm{N}$ & 30 & 30 \\
\cline { 2 - 3 } Minimum & $-0,17$ & 0.00 \\
\cline { 2 - 3 } Maximum & 0.92 & 0.90 \\
\cline { 2 - 3 } Mean & 0.471 & 0.670 \\
Std.Deviation & 0.298 & 0.218 \\
\hline
\end{tabular}




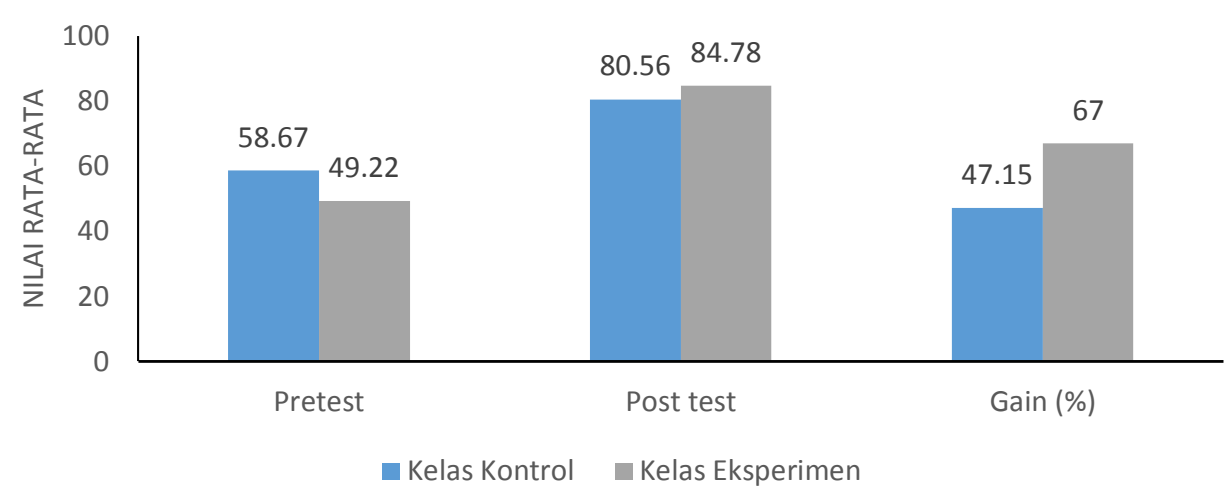

Gambar 2. Hasil Kemampuan Berpikir Analasis Siswa

Hasil uji t-Test untuk gain kelas kontrol dan kelas eksperimen pada pencapaian penguasaan dan kemampuan berpikir analisis adalah 0,019 untuk penguasaan konsep dan 0,002 untuk kemampuan berpikir analisis.

\section{Penguasaan Konsep}

Berdasarkan Tabel 1, siswa pada kelompok kelas eksperimen yang kemampuan awal lebih rendah mampu meningkatkan kemampuan penguasaan konsep lebih besar dibandingkan dengan kelompok kelas kontrol. Hal ini cukup membuktikan bahwa pembelajaran bounded inquiry labsmampu meningkatkan kemampuan mencari atau menemukan suatu permasalahan dan memecahkan permasalahan dengan lebih teratur dan terarah. Dengan menemukan sendiri maka siswa akan mengerti lebih dalam dan semakin bisa memecahkan permasalahan dengan lebih mudah. Wenning (2005) dalam inkuiri laboratorium siswa distimulasi dengan pertanyaan yang menggiring pada penemuan permasalahan tertentu, dan dibutuhkan kemampuan berpikir tingkat tinggi, sehingga siswa dengan mandiri melakukan aksi untuk memecahkan masalah yang dihadapai. Fase-fase pada pembelajaran bounded inquiry labsmengarahkan siswa untuk secara bertahap menemukan atau mengidentifikasi permasalahan secara ilmiah dan secara ilmiah pula siswa akan menyelesaikan permasalahan dan mampu mengkomunikasikan hasil penemuannya dengan baik. Penelitian ini semakin menguatkan penelitian yang sudah dilakukan oleh Ural (2016) yang menyatakan bahwa pembelajaran inkuiri laboratorium dapat meningkatkan sikap dan keingintahuan dan prestasi siswa dalam mata pelajaran kimia. Hasil penelitian ini sesuai juga dengan penelitian yang dilakukan oleh Xu dan Talanguer (2013) menyatakan bahwa pembelajaran inkuiri laboratorium dapat mengembangkan sikap refleksi siswa yaitu untuk melaksanakan pembelajaran ini dipengaruhi oleh peengetahuan, evaluasi dan perbaikan.

Berdasarkan Tabel 2 dan Gambar 1, korelasi kenaikan penguasaan konsep ini juga dapat dilihat dari gain antara kelas kontrol dan kelas eksperimen. Gain 
kelas eksperimen $(0,656)$ lebih besar dari gain kelas kontrol $(0,398)$ meskipun keduanya dalam katagori sedang. Nilai rata-rata kelas kontrol dan kelas eksperimen pada tes penguasaan konsep adalah hampir sama, namun gain untuk kelas eksperimen lebih baik dalam arti perlakuan penelitian ini berhasil menaikkan tingkat penguasaan konsep hidrolisis garam.

Untuk memperkuat kebenaran penelitian ini maka dilakukan juga uji independensi sampel (t-Test) yaitu untuk menguji keterkaitan antara pembelajaran bounded inquiry labsdengan penguasaan konsep siswa pada topik hidrolisis garam. Berdasarkan hasil uji t-test untuk penguasaan konsep siswa yang mempunyai tingkat signifikansi (sig. (2-tailed)) sebesar 0,019. Tingkat signifikasi ini lebih rendah dari 0,05 sehingga dapat disimpulkan bahwa Ho ditolak dan $\mathrm{H}_{1}$ diterima. Setelah mengikuti pembelajaran bounded inquiry labs peningkatan penguasaan konsep siswa lebih besar daripada pembelajaran langsung.

Dengan demikian dapat disimpulkan bahwa penguasaan konsep siswa dengan pembelajaran bounded inquiry labspada topik hidrolisis garam lebih baik dibandingkan dengan pembelajaran langsung.

\section{Kemampuan Berpikir Analisis}

Berdasarkan Tabel 3, hasil belajar kemampuan berpikir analisis di atas maka didapatkan hasil rata-rata nilai yang sangat kurang pada kemampuan berpikir analisis kelas kontrol maupun kelas eksperimen. Jika dibandingkan antara kelas kontrol dan kelas eksperimen, kemampuan rata-rata kelas kontrol lebih baik dari pada kelas eksperimen. Hal ini dapat kita lihat dari rata-rata pretest dari kedua kelas tersebut yaitu 58,66 untuk kelas kontrol dan 49,22 untuk kelas eksperimen, demikian juga untuk nilai terendah kelas kontrol (40) lebih baik dibandingkan dengan kelas eksperimen (23,33). Angka tersebut akan berkebalikan jika dilihat dari nilai postesnya, rata-rata nilai untuk kelas eksperimen lebih besar dari nilai rata-rata kelas kontrol yaitu 84,78 untuk kelas eksperimen dan 80,56 untuk kelas kontrol.

Dari data tersebut dapat disimpulkan bahwa pembelajaran bounded inquiry labs sangat membantu siswa untuk lebih meningkatkan kemampuan berpikir analisis siswa pada topik hidrolisis garam. Siswa lebih mengerti sifat-sifat larutan garam, bisa membedakan sifat keasaman larutan garam maupun dapat menghitung $\mathrm{pH}$ larutan garam karena siswa mengalami atau menemukan sendiri pengertian melalui langkah-langkah dalam pembelajaran bounded inquiry labs.

Pembelajaran bounded inquiry labs menuntut kemampuan berpikir tingkat tinggi. Salah satu berpikir tingkat tinggi adalah kemampuan berpikir analisis. Kemampuan menganalisis merupakan salah satu kemampuan berpikir yang terdapat dalam ranah kognitif untuk merinci atau menguaraikan suatu masalah menjadi bagian-bagian yang lebih kecil dan memahami hubungan antar bagian 
tersebut (Suherman dan Sukjaya, 1990). Dari data pencapaian kamampuan berpikir analisis dapat dinyatakan bahwa pembelajaran bounded inquiry labs sangat membantu siswa untuk lebih meningkatkan kemampuan berpikir analisis siswa pada topik hidrolisis garam. Siswa lebih mengerti sifat-sifat larutan garam, bisa membedakan sifat keasaman larutan garam maupun dapat menghitung $\mathrm{pH}$ larutan garam karena siswa mengalami atau menemukan sendiri pengertian melalui langkah-langkah dalam pembelajaran labs-inquiry jenis bounded inquiry.

Tabel 4 dan Gambar 2, menunjukkan korelasi kenaikan kemampuan berpikir analisis dapat juga dilihat dari $\mathrm{N}$-gain antara kelas kontrol dan kelas eksperimen. Gain kelas eksperimen $(0,67)$ lebih besar dari gain kelas kontrol $(0,47)$ meskipun keduanya dalam katagori sedang. Nilai rata-rata kelas kontrol dan kelas eksperimen pada tes kemampuan berpikir analisis tergolong baik, namun $\mathrm{N}$-gain untuk kelas eksperimen lebih baik dalam arti perlakuan penelitian ini berhasil menaikkan tingkat kemempuan berpikir analisis pada topik hidrolisis garam.

Hal ini cukup membuktikan bahwa model pembelajaran bounded inquiry labs mampu meningkatkan kemampuan mencari atau menemukan suatu permasalahan dan memecahkan permasalahan dengan lebih teratur dan terarah dengan bimbingan guru. Dengan menemukan sendiri maka siswa akan mengerti lebih dalam dan semakin bisa memecahkan permasalahan dengan lebih mudah. Fase-fase pada model pembelajaran bounded inquiry labs mengarahkan siswa untuk secara bertahap menemukan atau mengidentifikasi permasalahan secara ilmiah dan secara ilmiah pula siswa akan menganalisis dan kemudian menyelesaikan permasalahan dan mampu mengkomunikasikan hasil penemuannya dengan baik. Bidang studi kimia yang sebagian besar siswa menyatakan sukar, dengan melatih siswa untuk berpikir tingkat tinggi yaitu berpikir analisis maka bidang studi kimia yang dinyatakan sukar tersebut akan menjadi lebih mudah untuk dipahami siswa. Dengan langkah-langkah yang sesuai dengan indikator kemampuan berpikir analisis siswa diajak untuk memisahkan suatu materi pada bagian-bagiannya dan dapat mengetahui kaitan antar bagian tersebut sehingga dapat menarik kesimpulan dengan tepat, jadi kemampuan berpikir analisis siswa dapat membantu siswa dalam memecahkan permasalahan pada bidang studi kimia di sekolah.

Untuk menguatkan penelitian maka dilakukan uji t-test. Berdasarkan uji ttest untuk kemampuan berpikir analisis siswa mempunyai tingkat signifikansi (sig. (2-tailed)) sebesar 0,002. Tingkat signifikasi ini lebih rendah dari 0,05 sehingga dapat disimpulkan bahwa Ho ditolak dan $\mathrm{H}_{1}$ diterima. Setelah mengikuti pembelajaran bounded inquiry labs peningkatan kemampuan berpikir analisis siswa lebih besar daripada pembelajaran langsung. 
Dengan demikian dapat disimpulkan bahwa kemampuan berpikir siswa dengan pembelajaran bounded inquiry labs pada topik hidrolisis garam lebih baik dibandingkan dengan pembelajaran langsung. Berdasarkan hasil penelitian dengan uji t-Test untuk kedua variabel tersebut di atas maka pembelajaran bounded inquiry labs meningkatkan penguasaan konsep dan kemampuan berpikir analisis siswa pada topik hidrolisis garam.

Penelitian ini sesuai dengan penelitian yang sudah dilakukan oleh para peneliti sebelumnya antara lain adalah penelitian dari Wulandari, K.F.N., dkk (2017) yang menyimpulkan bahwa pengembangan pembelajaran inkuiri laboratorium yang dipadukan dengan pembelajaran pembelajaran two stay two stray (IL-2TS) pada materi system ekskresi dapat memberdayakan kemampuan analisis dan komunikasi siswa; Nilgin, T. (2012) menyatakan bahwa penerapan pembelajaran saintifik inkuiri berbasis laboratorium (inquiry-based science laboratories) meningkatkan keyakinan guru dalam pemahaaman pembelajaran ilmiah pada bidang studi IPA

\section{PENUTUP}

Pembelajaran bounded inquiry labs mengajak siswa untuk menemukan permasalahan dan memecahkan masalah secara mandiri yang di dukung oleh data dari hasil ekeperimen di laboratoium. Kemampuan untuk memecahkan masalah secara mandiri ini diperlukan kemampuan berpikir analisis yang baik. Pembelajaran bounded inquiry labs mampu meningkatkan penguasaan konsep dan kemamapuan berpikir analisis siswa dalam pemecahan masalah kimia terutama materi hidrolisis garam.Berdasarkan angket yang sudah disebar dan diberikan kepada siswa kelas eksperimen didapatkan hasil sebagai berikut: sebagian besar siswa menyukai menyukai pembelajaran dengan praktikum di laboratorium dengan pembelajaran bounded inquiry labs, yang membantu meyelesaikan masalah, meningkatkan prestasi penguasaan konsep (ulangan), dan siswa merasa sangat dilibatkan dalam proses pembelajaran. Siswa berharap pembelajaran bounded inquiry labs diterapkan juga pada topik-topik kimia yang lain.

Hasil penelitian ini memberikan masukan kepada guru, bahwa pembelajaran bounded inquiry labs dapat digunakan dalam pembelajaran kimia pada materi hidrolisis garam. Metode ini melatih siswa untuk berpikir tingkat tinggi yaitu kemampuan berpikir analisis. Kepada guru bidang studi kimia, untuk mengajarkan konsep-konsep kimia diperlukan metode yang tepat, sehingga siswa lebih mudah memahami materi. Dalam menentukan metode pembelajaran guru sebaiknya memperhatikan karakteristik dari materi sehingga metode yang diajarkan sesuai. Materi kimia hidrolisis garam memerlukan kegiatan praktikum dilaboratorium, siswa dapat berinteraksi langsung dengan sumber materi, 
sehingga siswa lebih mudah mengingat konsep materi yang diajarkan. Penelitian ini dapat digunakan sebagai acuan melakukan penelitian yang sama, namun perlu dipadukan dengan metode pembelajaran yang lain

\section{REFERENSI}

Dahar,Ratna Wilis. (2011). Teori Teori Belajar dan Pembelajaran. Jakarta: Erlangga

De Gale,S., \& Boisselle, L.N. (2015). The Effect of POGIL on Academic Performance and Academic Confidence. Journal of Science Education International. 26 (1), 56-61.

Fraenkel, J.R., \& Wallen, N.E. (2006). How To Design and Evaluate Research in Education. New York : McGraw-Hill Humanities/Social Sciences.

Herdian. (2010). Kemampuan Berpikir Analitis. Retrieved from http ://herdy07.wordpress.com/2010/05/27/kemampuan-berpikir-analitis/

Nilgin, T. (2012). Inquiry-Based Science Laboratories: An Analysis of Pre service Teachers' Beliefs about Learning Science through Inquiry and Their Performances. Journal of Baltic Science Education, 11 (3), 248-256.

Robbins, J.K. (2011). Problem Solving, and Analytical Thinking in a Classroom Environment. Morningside Academy and Partnerships for Educational Excellence and Research International, 12 (1), 41-48.

Sudjana, N. (2005). Penelitian Hasil Proses Belajar Mengajar. Bandung: PT. Remaja Rosda Karya.

Suherman, E. dan Sukjaya, Y. (1990). Petunjuk Praktis untuk Melaksanakan Evaluasi Pendidikan Matematika. Bandung : Wijayakusumah.

Ural, E. (2016). The Effect of Guide-Inquiry Laboratory Experiments on Science Education Students' Chemistry Laboratory Attitudes, Anxiety and Achievement. Journal of Education and Training Studies, 4 (4), 217-227.

Wenning, C.J. (2005). Levels of Inquiry: Hierarchies of Pedagogical Practice and Inquiry Processes. Journal of Physics Teacher Education online, 2(3), 312.

Wenning, C.J. (2011). Levels of Inquiry Model of Science Teaching. Journal of Physics Teacher Education, 6(2), 9-16.

Wulandari, K.F.N., Sajidan, Sugoyarto. (2017). Pengembangan Pembelajaran Inkuiri Laboratorium Yang Dipadukan Dengan Pembelajaran Pembelajaran Two Stay Two Stray (IL-2TS) Pada Materi System Ekskresi Dapat Memberdayakan Kemampuan Analisis Dan Komunikasi Siswa. Jurnal Inquir, 6, 27-34.

$\mathrm{Xu}$, H. \& Talanguer, V. (2013). Effect of The Level of Inquiry of Lab Experiments on General Chemistry Students' Written Reflection. Journal Of Chemistry Education. 90, 21-28. 